\title{
Plant invasion: Some gleanings from Madhava Chikitsa
}

\author{
D. A. Patil \\ Post-Graduate Department of Botany, S.S.V.P. Sanstha's L.K. Dr. P.R. Ghogrey Science College, Dhule-424005 \\ Maharashtra, India \\ *Corresponding Author: dapatil_10aug@yahoo.com
}

\begin{abstract}
Medicolore is intimately rooted in ancient Sanskrit compendia in Ayurveda. Ayurveda during $5^{\text {th }}-10^{\text {th }}$ century AD in the Charak-Sushruta era became user-friendly. One such attempt is Madhava Chikitsa conceived and written by Madhacharya in 7th century. Of late, the scientific all-pervasive examination is being carried out. The present author studied it from the standpoint of plant invasion in erstwhile India. Total of 42 exotic plant species pertaining to 41 genera and 30 families of angiosperms have been documented from it. The majority of them ( 28 species) are under cultivation in India and rest others run wild on Indian landmass. Their nativity is also brought in a clearer focus. Maximum species appeared invaded from Europe (11 species), America (09 species), Africa and Asia (Excluding India) (06 species each), other countries, continents or regions are represented by one or two species each. The consequence of plant invasion is interpreted in Indian context. Our understanding can be enriched to suggest measures for conservation of nature if such introductions of plants revealed from ancient literary sources of India.
\end{abstract}

Keywords: Madhava Chikitsa, Exotics, Plant Invasion.

\section{INTRODUCTION}

A $7^{\text {th }}$ century AD Indian physician Madhavacharya designed, conceived and wrote two treatises viz., Madhava Nidana and Madhava Chikitsa which dealt with human diseases, their causes, symptoms and remedial measures. His work is compiled on the foundations of knowledge resourced from earlier Samhita and Samgraha in Ayurveda. It still enjoys an independent respected and important treatise having unique content and written in its style. His formulations are thought original and based either on single drugs or in combinations. Madhava Chikitsa sheds more light on disease management and therapeutics, whereas Madhava Nidana dealt with medical diagnostics. The manuscript of Madhav Chikitsa remained unpublished and deposited in the Saraswati Library, Udaipur (Rajasthan, India) and recently published by Ayurveda Vishwa Bharati, Sardar Shahar (Rajasthan) in 1973. It is now also available with Bhandarkar Institute for Oriental Research, Pune (Maharashtra, India). Its importance has been unearthed, of late, (Sastry \& Prasad, 2007; Mishra 2009; Krishnamurthy, 2012). Several translations in different languages in India and abroad are also now available. It has remained untouched from viewpoint of plant invasion on the Indian subcontinent as it also includes exotic plant species as sources of his formulations. Ancient scripts reflect human contacts, trade and ecological information of the said period or even earlier ones. The present author analysed the exotic floral content contained in it revealing plant invasion on the erstwhile Indian subcontinent.

\section{METHODOLOGY}

Madhava Chikitsa (Authored by Krishnamurthy 2012) in Sanskrit and English was consulted. This treatise explains original Sanskrit verses about medicinal recipes of plant origin. The plant species have Sanskrit names. They are verified for botanical identity consulting related literature (Chopra et al., 1956; Sharma, 1956, 2003; Thakur \& Chunekar, 1972; Sharma, 2001-2005; Khare, 2007). The nativity of each species is pointed out using relevant literary sources mentioned against each species as in table 1. Various floras mentioned in the references were also helpful while determining the plant species.

\section{RESULTS}

This study brought to light 42 exotic angiosperm species from the Madhava Chikitsa (Table 1). They belong to 41 genera and 30 families. Of these, 28 exotic species are generally cultivated, whereas 13 species occur in India as naturalised wild aliens. A single species viz., Cassia fistula L. found wild as well as planted in gardens as ornamental. All these species have been mentioned in the said manuscripts useful medicinally in ancient times especially before $7^{\text {th }}$ century. They appear brought intentionally or unintentionally. The cultivated ones appear introduced for most sources of the food adjuncts and aromatics. The wild ones have now become an integral part of Indian biodiversity. The cultivated ones, as also the wild species have been appropriated by trial and errors and after experimentation as 
medicinal sources by the Indian community in ancient times. The analysis of their nativity reveals that the maximum number of exotic species belongs to, in descending order, Europe (11 species), America (09 species), Africa (06 species) and Mediterranean region (04 species) and Afghanistan and China (03 species). Other countries represent either two species each e.g. Malaysia, Ceylon/Srilanka, and Indonesia. There are some countries that contributed a single species each such as Australia, Philippines, Persia, Pakistan, West Indies, Java, etc. These are indicative of a fact that the ancient Indians have contacts, whether direct or indirect, with the various parts of the world.

Table 1. Exotic plants divulged from ancient treatise Madhava Chikitsa.

\begin{tabular}{|c|c|c|c|c|}
\hline S.N. & Scientific Name & Family & Sanskrit Name & Nativity \\
\hline 1 & Albizia lebbeck Benth. & Mimosaceae & Sirisa & $\begin{array}{l}\text { Pantroical Africa \& Tropical Asia } \\
\text { (Bhandari, 1978) }\end{array}$ \\
\hline 2 & Allium sativum $\mathrm{L}$. & Liliaceae & Lasunah, Rasona & $\begin{array}{l}\text { Europe } \\
\text { (Gaikwad \& Garad, 2015; Yadav \& } \\
\text { Sardesai, 2002) }\end{array}$ \\
\hline 3 & Amaranthus tricolor $\mathrm{L} . *$ & Amaranthaceae & Ramasitalika & $\begin{array}{l}\text { Asia (Excl. India) \& Africa } \\
\text { (Stewart, 1972) } \\
\text { Tropical Asia } \\
\text { (Yadav \& Sardesai, 2002) }\end{array}$ \\
\hline 4 & $\begin{array}{l}\text { Anethum graveolens } \mathrm{L} . \\
\text { [= A. sowa Roxb. ex Flem.] }\end{array}$ & Apiaceae & Satahvaya & $\begin{array}{l}\text { Europe } \\
\text { (Yadav \& Sardesai, 2002; Patil, 2003) }\end{array}$ \\
\hline 5 & Boerhavia diffusa L. * & Nyctaginaceae & Punarnava & $\begin{array}{l}\text { Tropical Africa } \\
\text { (Panda } \text { et al., 2018) }\end{array}$ \\
\hline 6 & Brassica compestris L. var. sarso Prain & Brassicaceae & Saraeapa & $\begin{array}{l}\text { Europe } \\
\text { (Naqshi \& Javeid, 1987) }\end{array}$ \\
\hline 7 & Carum carvi $\mathrm{L}$. & Apiaceae & Karavi & $\begin{array}{l}\text { North \& Central Europe } \\
\text { (Patil \& Dhale, 2013) }\end{array}$ \\
\hline 8 & Cassia fistula $\mathrm{L} . * *$ & Caesalpiniaceae & Sampaka & $\begin{array}{l}\text { North America } \\
\text { (Debnath \& Debnath, 2017) }\end{array}$ \\
\hline 9 & Cinnamomum camphora Nees \& Eberm. & Lauraceae & Hima & $\begin{array}{l}\text { China \& Japan } \\
\text { (Benthall, 1946) }\end{array}$ \\
\hline 10 & $\begin{array}{l}\text { Cinnamomum zeylanicum Blume } \\
\text { [= C. verum Presl.] }\end{array}$ & Lauraceae & Travk & $\begin{array}{l}\text { Ceylon (Sri Lanka) } \\
\text { (John, 1891) }\end{array}$ \\
\hline 11 & $\begin{array}{l}\text { Cissampelos pareira L. var. hirsuta } \\
\text { (Buch.-Ham. ex DC.) Forman * }\end{array}$ & Menispermaceae & Patha & $\begin{array}{l}\text { South America } \\
\text { (Rajagopal \& Panigrahi, 1965; Pandu } \\
\text { et al., 2018) }\end{array}$ \\
\hline 12 & Coriandrum sativum $\mathrm{L}$. & Apiaceae & Dhanyaka & $\begin{array}{l}\text { Mediterranean Region } \\
\text { (Shetty \& Singh, 1987) }\end{array}$ \\
\hline 13 & Cuminum cyminum $\mathrm{L}$. & Apiaceae & Svetajiraka & $\begin{array}{l}\text { South Europe } \\
\text { (Yadav \& Sardesai, 2002) } \\
\text { Mediterranean Region } \\
\text { (Shetty \& Singh, 1987) }\end{array}$ \\
\hline 14 & Cymbopogon citratus (DC.) Stapf & Poaceae & Sugandhitrana & $\begin{array}{l}\text { Malaysia \& Ceylon } \\
\text { (Purseglove, 1968) }\end{array}$ \\
\hline 15 & Cyperus rotundus L. * & Cyperaceae & Musta & $\begin{array}{l}\text { Europe } \\
\text { (Kaul, 1986; Panda et al., 2018) } \\
\text { Tropical Africa } \\
\text { (Debnath \& Debnath, 2017) }\end{array}$ \\
\hline 16 & $\begin{array}{l}\text { Eclipta prostrata }(\mathrm{L} .) \mathrm{L} . \\
{[=\text { E. alba } \text { Hassk.] * }}\end{array}$ & Asteraceae & Bhringaraja & $\begin{array}{l}\text { South \& Tropical America } \\
\text { (ChandraSekar, 2012; Patil, 2017; } \\
\text { Reddy, 2008) }\end{array}$ \\
\hline 17 & Ferula assafoetida Regel & Apiaceae & Hingu & $\begin{array}{l}\text { Central Asia, Eastern Iran to } \\
\text { Afghanistan } \\
\text { (Mahendra \& Bisht, 2012) }\end{array}$ \\
\hline 18 & Fumaria indica (Haussk.) Pugsley* & Fumariaceae & Parpaka & $\begin{array}{l}\text { Pakistan \& Afghanistan } \\
\text { (Negi \& Hajra, 2007) }\end{array}$ \\
\hline 19 & Glycyrrhiza glabra L. & Papilionaceae & Madhukam & $\begin{array}{l}\text { Eurasia, Northern Africa \& Western } \\
\text { Asia } \\
\text { (Ali Al-Snafi, 2018) }\end{array}$ \\
\hline 20 & Hordeum vulgare $\mathrm{L}$. & Poaceae & Yava & $\begin{array}{l}\text { Europe \& North America } \\
\text { (Dar et al., 2002) }\end{array}$ \\
\hline
\end{tabular}


21 Lens culinaris Medic.

22 Luffa acutangula (L.) Roxb.

23 Melia azaderach $\mathrm{L}$.

24 Mimosa pudica L.

25 Mucuna pruriens (L.) DC.

26 Oxalis corniculata L. *

27 Peristrophe paniculata (Forssk.) Brummit* [= P. bicalyculata (Retz.) Nees]

28 Piper retrofractum Vahl. [= P. chaba Hunter]

29 Pistacia chinensis Bunge.

30 Plectranthus scutellaroides (L.) R.Br [= Coleus scutellaroides (L.) Benth.]

31 Plumbeago zeylanica L. *

32 Punica granatum L.

33 Ricinus communis L.

34 Rubia cordifolia L

35 Sesbania grandiflora Pers.

36 Sida cordifolia L. *

37 Trachyspermum ammi (L.) Sprague $[=T$. natans $\mathrm{L}$. var. bispirosa Roxb. $]$

38 Trapa bispinosa Roxb.

39 Tribulus terrestris L. *

$40 \quad$ Vernonia cinerea Less. *

41 Vitis vinifera $\mathrm{L}$.

$\begin{array}{ll}\text { Papilionaceae } & \text { Masura } \\ \text { Cucurbitaceae } & \text { Krtavedhan } \\ \text { Meliaceae } & \text { Mahiniba } \\ \text { Mimosaceae } & \text { Krtanjali } \\ \text { Papilionaceae } & \text { Vanari } \\ \text { Oxalidaceae } & \text { Cangeri } \\ \text { Acanthaceae } & \text { Kakajangha } \\ \text { Piperaceae } & \text { Gajahva } \\ & \\ \text { Anacardiaceae } & \text { Karkaoa } \\ \text { Lamiaceae } & \text { Udicya } \\ \text { Plumbaginaceae } & \text { Vahni }\end{array}$

Punicaceae

Dadima

Euphorbiaceae Eranda

Papilionaceae

Malvaceae

Apiaceae

Trapaceae

Srigataka

Zygophyllaceae

Gokaeura

Asteraceae

Sahadevi

Vitaceae
Central Europe, Mediterranean Region \& West Asia

(Patil, 1995)

Tropical Asia (John, 1891)

Asia (Excl. India)

(Ara et al., 1995)

Brazil

(Shetty \& Singh, 1987)

America

(Singh \& Nigam, 2017)

Europe

(Reddy, 2008; ChandraSekar, 2012)

North America

(Babu, 1977)

Tropical America

(Reddy, 2008; Patil, 2017;

ChandraSekar, 2012)

Native of Southern China, Malaysia, Indonesia, Philippines \& Indo-China (Tropical Plant Database 2019)

\section{China}

(Tang et al., 2012)

Java

(Yadav \& Sardesai, 2002)

Tropics of Asia, Africa, Australia \& Hawaii

(Bailey, 1930)

Africa

(Rajagopal \& Panigrahi, 1965)

Afghanisthan, Baluchistan \& Persia (Shetty \& Singh, 1987; Patil, 2003)

South Asia

(Gaikwad \& Garad, 2015)

Tropical Africa

(Yadav \& Sardesai, 2002)

Africa

(Stewart, 1972)

Asia (Excl. India) \& Africa

(Kaul, 1986)

Indonesia

(Patil, 1995)

Tropical \& Subtropical Regions of both Hemispheres

(Bhandari, 1978)

South Europe

(Yadav \& Sardesai, 2002; Gaikwad \&

Garad, 2015)

Africa

(Shetty \& Singh, 1987)

Europe

(Kak, 1990)

Tropical America

(ChandraSekar, 2012; Reddy, 2008)

Africa \& Asia (Excl. India)

(Kaul, 1986)

South America

(Debnath \& Debnath 2017)

South-East Europe To West Indies

(Singh et al., 2000)

Asia (Excl. India) \& Europe

(Stewart, 1972) 


\begin{tabular}{llcl}
\hline 42 Ziziphus jujuba Mill. & Rhamnaceae & Kola & $\begin{array}{l}\text { Subtropics \& Warm Temperate Zone } \\
\text { (Martin } \text { et al., 1987) }\end{array}$ \\
\hline
\end{tabular}

Note: $*=$ Exclusively wild; $* *=$ Wild \& Cultivated.

\section{DISCUSSION}

There is a recent trend to unearth plantlore from the ancient Indian Literature. Katti (1991), Krishnamurthy (1996) and Amirthalingam \& Sudhakar (2013) revealed plant and animal diversity in Valmiki's Ramayana. Mahendale (1986) studied floral elements contained in Aranyakaparvan of Mahabharata. Patil (2017) investigated ancient Vedic and PostVedic literature in view of plant invasion. These ancient monumental works inform on biodiversity prevailing in those periods. The diversity of nature has always fascinated mankind since the ancient times. The glory, beauty and utility of the biodiversity elements is integrated in the ancient scripts written by ancient Indian sages, philosophers and writers. They had commendable knowledge of the plant kingdom of their land and time which is reflected in their works. The present author also examined Madhava Chikitsa, a $7^{\text {th }}$ centurian manuscript commenting on medicinal utilities borrowed partly the past ancient Sanskrit literature and epitomes with his own experience and knowledge about medicinal plant species. He mentioned several plants, indigenous or exotic ones. However, these floral elements are not focused earlier from the point of biological invasion on Indian landmass. The present study made an inquiry into them, the results of this investigation are presented in this communication.

The plant species added or cultivated have a positive impact on the economy and lifestyle of the people being an addition or new utilitarian sources. However, other wild taxa invaded in India have been also found useful medicinally. Some of them are, however, invasive aliens e.g. Cyperus rotundus L., Eclipta prostrata (L.) L., Peristrophe paniculata (Forssk.) Brummit, Vernonia cineraria Less., etc. Convention for Biological Diversity (1992) considered biological invasion of alien species as the second worst threat after habitat destruction.

\section{CONCLUSIONS}

After successful local establishment, such invasive alien species disperse and produce variable seeds, propagules or offsprings in areas distant from the sites of introduction. Many times, they are ready colonizers in disturbed areas and cause considerable damage ecologically. They are also responsible for the disappearance of threatened and endemic species. They reduce the carrying capacity of pastures and increase the maintenance costs of croplands. The plant world and the human world act and react with each other in different ways, positively or negatively. Conservation of nature, preservation of ecological equilibrium and the protection of the environment have become a watchword in recent time. These concepts emerged out of our better understanding of nature. Our understanding on this line can be enriched more if we unearth knowledge of the ancient people embodied in such manuscripts such as Madhava Chikitsa.

\section{ACKNOWLEDGEMENTS}

The author is thankful to the authorities of S.S.V.P. Sanstha (Dhule) for necessary facilities extended during the tenure of research.

\section{REFERENCES}

Ali Esmail \& Al-Snafi (2018). Glycyrrhiza glabra: A phytochemical and pharmacological review. IOSR Journal of Pharmacy, 8(6): $1-17$.

Amirthalingam M. \& Sudhakar P. (2013). Plant And Animal Diversity in Valmiki's Ramayana. C.R.P. Environmental Education Centre, Chennai, Tamil Nadu, India.

Ara S., Naashi A.R. \& Baba M.Y. (1995). Indigenous and exotic trees and shrubs of Kashmir. Indian Journal of Forestry, 8: 233272.

Babu C.R. (1977). Herbaceous Flora of Dehra Dun. CSIR Publications, New Delhi, India.

Bailey L.H. (1930). The Standard Cyclopedia of Horticulture (England Edition). Vol.II. Macmillan, New York, USA.

Benthall A.P. (1946). Trees of Calcutta and Its Neighbourhood. Thacker, Sprink, Calcutta, India.

Bhandari M.M. (1978). Flora of The Indian Desert. Scientific Publishers, Jodhpur, India.

ChandraSekar K. (2012). Invasive alien plants of Indian Himalayan region: Diversity and implication. American Journal of Plant Sciences, 3: 177-184.

Chopra R.N., Nayar S.L. \& Chopra I.C. (1956). Glossary of Indian Medicinal Plants. Publication \& Information Directorate, New Delhi, India.

Dar G.H., Bhagat R.C. \& Khan M.A. (2002). Biodiversity of The Kashmir Himalaya. Valley Book House, Srinagar, India.

Debnath A. \& Dehnath B. (2017). Diversity, invasion status and uses of alien plant species in North Eastern Hilly States of Tripura: A confluence of Indo-Barman hotspot. American Journal of Plant Sciences, 8: 212-235.

Gaikwad S.P. \& Garad K.U. (2015). Flora of Solapur District. Laxmi Book Publications, Solapur, Maharashtra, India. 
John C. (1891). Catalogue of Plants In The Botanical Garden, Bangalore And its Vicinity, $2^{\text {nd }}$ Ed. Mysore Government Central Press, Bangalore, India.

Kak A.M. (1990). Aquatic and wetland vegetation of Kashmir Himalaya. Journal of Economic and Taxonomic Botany, 14: 1-14.

Katti M.S. (Ed.) (1991). Srimad Valmiki Ramayana (with commentaries-Tilaka of Rama, Ramayana Shiromani of Shivasahaya and Bhushana of Govinidaraja). Parimal Publications, New Delhi, India.

Kaul M.K. (1986). Weed Flora of Kashmir Valley. Scientific Publishers, Jodhpur, India.

Khare C.P. (Ed.) (2007). Indian Medicinal Plants: An Illustrated Dictionary. Springer Science + Business Media, LLC, New York, USA.

Krishnamurthy K.H. (1996). A botanical account of Valmiki's Panchavati. Indian Journal of History of Science, 31(2): $131-156$.

Krishnamurthy M.S. (2012). Madhava Chikitsa. Chaukhamba orientalia, Varanasi, India.

Mahendale M.A. (1986). The flora in the Aranyakaparvan of the Mahabharata. Annals of The Bhandarkar Oriental Research Institute. LXVII: 233-242.

Mahendra P. \& Bisht S. (2012). Ferula asafoetida: Traditional uses and pharmacological activity. Pharmacognosy Review 6(12): 141146.

Martin F.W., Campbell C.W. \& Ruberte R.M. (1987). Perennial Edible Plants of The Tropics: An Inventory. U.S. Department of Agriculture, Agriculture Handbook No. 642. 222 p. illus.

Mishra D.N. (2009). Medicinal plants for the treatment of fever (Jvara Cikitsa) in the Madhava Chikitsa tradition of India. Indian Journal of Traditional Knowledge, 8: 352-361.

Naqshi A.R. \& Javeid G.N. (1987). Tribe Brassiceae (Brassicaceae) in Kashmir Himalaya. Journal of Economic and Taxonomic Botany, 9: 89-96.

Negi P.S. \& Hajra P.K. (2007). Alien flora of Doon Valley, Northwest Himalaya. Current Science, 92(7): 968-978.

Panda T., Mishra N., Pradhan B.K. \& Mohanty R.B. (2018). Expansive alien fora of Odisha, India. Journal of Agriculture and Environment for International Development, 112(1): 43-64.

Patil D.A. \& Dhale D.A. (2013). Spices and Condiments: Origin, History and Applications. Daya Publishing House, New Delhi, India.

Patil D.A. (1995). Exotic elements in the flora of Dhule district (Maharashtra)-II. Biojournal, 7(1-2): 1-8.

Patil D.A. (2003). Flora of Dhule And Nandurbar Districts (Maharashtra). Bishen Singh Mahendra Pal Singh, Dehradun, India.

Patil D.A. (2017). Alien plant species recorded in Vedic and Post-Vedic period of India: An assessment. Scholars Academic Journal of Biosciences, 5(17): 812-819.

Patil D.A. (2017). Invasive alien species in Khandesh region (Maharashtra, India): Diversity, implications and measures. Scholars Academic Journal of Biosciences, 5(12): 867-876.

Purseglove J.W. (1968). Tropical Crops-Dicotyledons. 2 Vols. Longmans, London, UK.

Rajagopal T. \& Panigrahi G. (1965). 'Aliens' naturalised in the flora of Allahabad. Proceedings of the National Academy of Sciences India Section B, 35(4): 411-422.

Reddy C.S. (2008). Catalogue of Invasive Alien Flora of India. Forestry and Ecology Division, National Remote Sensing Agency, Balanagar, Hyderabad-500037, India.

Sastry J.L. \& Prasad V.L. (2007). Madhava Cikitsa. Satraumala (Treatment of Diseases mentioned in Madhava Nidana) Chaukhamba Orientalia, Varanasi, India.

Sharma P.C. (2001-2005). Database On Medicinal Plants Used in Ayurveda. Vol. 1-7. Central Council For Research In Ayurveda And Siddha (CCRAS), Government of India, New Delhi, India.

Sharma P.V. (1956). Dravyaguna Vijnana. Vol. II-III. Vidyabhavan Ayurveda Granthmala, Chowkhamba Vidya Bhawan, Banaras, India.

Sharma P.V. (2003). Dravyaguna kosah. Acharya Priyavrat Sharma Ayurveda Series No.2, Chowkhamba Orientalia Banaras, India.

Shetty B.V. \& Singh V. (1987). Flora of Rajasthan, Vol. I. Botanical Survey of India, Calcutta, India.

Singh A.K. \& Nigam S.N. (2017). Ancient alien crop introductions integral to Indian agriculture. An overview. Proceedings of the National Academy of Sciences India Section B, 83(3): 549-568.

Sirkar N.N. \& Sarkar Roma Vrksayurveda of Parasara (A Treatise On Plant Science). Sri Satguru Publications (A Division Of Indian Books Centre) Delhi, India.

Stewart R.R. (1972). An Annotated Catalogue of The Vascular Plants of West Pakistan and Kashmir. Fakhri Press, Karachi, Pakistan.

Tang M., Zhang P., Zhang L., Li M. \& Fu L. (2012). A potential bioenergy tree: Pistacia chinensis Bunse. Energy Procedia, 16: 737746.

Thakur B.S. \& Chunekar K.C. (1972). Glossary of Vegetable Drugs in Brihatrayi. The Chowkhamba Sanskrit Studies, Vol. 87 (1 $1^{\text {st }}$ Ed.). Chowkhamba Sanskrit Series Office, Varanasi, India.

Tropical Plant Database (2019). Ken Fern. tropical.theferns.info.2019-09-21.

Yadav S.R. \& Sardesai M.M. (2002). Flora of Kolhapur District. Shivaji University, Kolhapur, Maharashtra, India. 